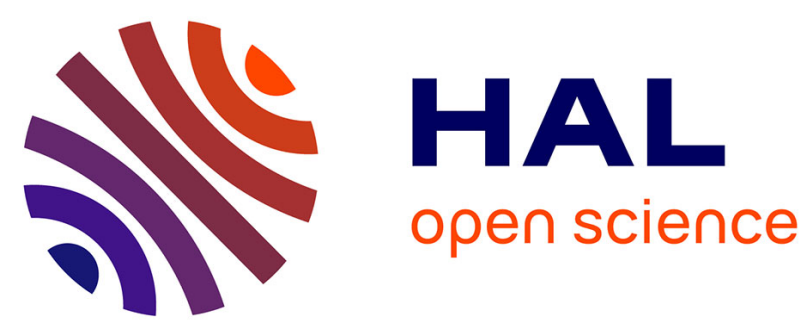

\title{
Summer drought impacts annual shoot growth dynamics in apple tree: a comparative study on three cultivars
}

Benoit Pallas, Dianyu Chen, Sébastien Martinez, Youke Wang, Evelyne Costes

\section{To cite this version:}

Benoit Pallas, Dianyu Chen, Sébastien Martinez, Youke Wang, Evelyne Costes. Summer drought impacts annual shoot growth dynamics in apple tree: a comparative study on three cultivars. 30. International Horticultural Congress IHC2018, Aug 2018, Istanbul, Turkey. hal-02736930

\section{HAL Id: hal-02736930 \\ https://hal.inrae.fr/hal-02736930}

Submitted on 2 Jun 2020

HAL is a multi-disciplinary open access archive for the deposit and dissemination of scientific research documents, whether they are published or not. The documents may come from teaching and research institutions in France or abroad, or from public or private research centers.
L'archive ouverte pluridisciplinaire $\mathbf{H A L}$, est destinée au dépôt et à la diffusion de documents scientifiques de niveau recherche, publiés ou non, émanant des établissements d'enseignement et de recherche français ou étrangers, des laboratoires publics ou privés. 


\title{
Summer drought impacts annual shoot growth dynamics in apple tree: a comparative study on three cultivars
}

Benoît Pallas¹, Dianyu Chena1,2, Sébastien Martinez ${ }^{1}$, Youke Wang ${ }^{3}$, and Evelyne Costes ${ }^{1 *}$

1 AGAP, Univ. Montpellier, CIRAD, INRA, Montpellier SupAgro, Equipe Architecture et Fonctionnement des Espèces Fruitières, Montpellier, France. ${ }^{2}$ College of Water Resources and Architectural Engineering, Northwest A\&F University, Yangling 712100, Shaanxi, China. ${ }^{3}$ Institute of Soil and Water Conservation, Northwest A\&F University, Yangling 712100, Shaanxi, China.

a Both authors equally contributed to this study

*Corresponding author:

Tel: +33 (4) 67617508

E-mail: evelyne.costes@inra.fr

\begin{abstract}
Plants respond to drought by adjusting different growth and developmental processes. This study investigated the impact of a summer water deficit on shoot growth dynamics, comparatively in three apple cultivars, in their second and third year of growth.

Trees were differentially irrigated to induce water stress (WS) or well-watered conditions (WW). WS effects were evaluated on long shoots in either terminal or lateral position, by observing metamer appearance rate, growth duration and arrest time.

In the three cultivars, WS promoted growth cessations (GC) during summer leading to bicyclic shoots. These GC occurred early in the season, when WS conditions were mild. Consistently with tree ontogeny, the number of shoots that resumed growth after summer arrest decreased between the two consecutive years, but more in WS than WW conditions. In both monocyclic and bicyclic shoots, WS provoked a more precocious GC at the end of the growth season.

Even though WS impact slightly differed among cultivars, a reduction in shoot neoformation and an increase in summer arrest appeared as a common response of apple tree to water deficit. This can be interpreted as an avoidance strategy to reduce the tree leaf area, leading to a modification of the within-tree shoot demography in favor of medium and short shoots.
\end{abstract}

Keywords: drought, shoot growth dynamics, rhythmic growth, tree architecture, Malus $\mathrm{x}$ domestica 